\title{
AGRICULTURAL MECHANIZATION IN GHANA: ALTERNATIVE SUPPLY MODELS FOR TRACTOR HIRING SERVICES
}

\author{
Xinshen Diao and Hiroyuki Takeshima
}

\begin{abstract}
As in most countries in Africa, agricultural mechanization in Ghana was slow to develop until the 1990s; however, this has changed markedly since the early 2000s. According to the nationally representative Labor Force Survey conducted in 2015/2016, about one third of Ghana's crop-growing farmers, including smallholders, reported using some form of machinery, mostly tractors for land preparation. Still, policymakers are concerned that mechanization should be proceeding at a faster rate and worry that supply-side issues may be constraining its uptake, especially among smallholders. With this in mind, the government recently started to directly re-engage the promotion of mechanization, devoting public resources to directly subsidize machinery imports and to establish a network of subsidized agricultural mechanization service centers around the country (Diao et al. 2014). Parallel with these government programs is the rapid development of private-sector supply systems, through which an increased number of secondhand tractors were imported and purchased by relatively largescale farmers. In turn, these farmers provide hiring services to smaller-scale farmers for use mainly in land preparation, harvesting, and threshing. In this chapter, we review recent developments in the uptake of agricultural mechanization in Ghana and the factors driving the growth in farmers' demand. We then discuss alternative supply models in the country, comparing them with recent government interventions. This leads to our conclusions about appropriate mechanization policies for the future.
\end{abstract}

\section{A Historical Overview of Mechanization in Ghana}

Ghana is a relatively land-abundant country, but agriculture, which was the mainstay of the economy until the late 1990s, is still dominated by small firms. Mechanized agriculture has existed since before independence among a few large-scale farmers; however, even though land was available for farm 
expansion in many places, overall mechanization levels have been low until recently.

Like the country's early industrialization strategy, state-led direct interventions characterized agricultural policies in the 1960-1970s. Under such policies, the government promoted large-scale mechanized farming through a series of intervention programs such as the famous Operation Feed Yourself (OFY) program (Girdner et al. 1980), the Upper Regional Agricultural Development Project, and the Volta Regional Agricultural Development Project (Okolie 2003). In combination with protectionist policies in trade and markets, including rice import controls and local rice price support policies (Abdulai and Huffman 2000), the large-scale agriculture promotion policies led to the establishment of largely mechanized large estate farms, particularly in rice production areas in northern Ghana (Amanor 2011). Tractors that were imported for these large farms were implicitly subsidized by the significantly overvalued exchange rate. In the meantime, the government of Ghana, similarly to governments in many other African countries including Nigeria, Zambia, and Tanzania, sought to promote tractorization of subsistence farmers through the establishment of tractor hiring services (THS) schemes operated by the government (Akinola 1987). According to Seager and Fieldson (1984), the Ministry of Agriculture in the 1960s owned and operated 1,500 tractors in its 32 district mechanization stations in the savannah zone. The low service charges paid by farmers for the service provision of land clearing, tillage, and harvesting were estimated to be about 3-74 percent of actual costs, depending on the service rendered (Stryker et al. 1990). With the focus shifting to rice-growing areas in the 1970s, the heavily subsidized mechanization model was further expanded in the north, where rice was grown. Of a total of 239 heavy farm machines operated by the Ministry of Agriculture in the 1970s, about 40 percent were in the Northern and Upper regions and mainly used for rice production. Similarly, about 60 combine harvesters were operated by the Ministry of Agriculture in the northern rice-growing zones (Akoto 1987).

As expected, low efficiency arose as result of the heavily subsidized and state-run THS schemes. It was estimated that only about 40 percent of the government tractors were serviceable and each of these plowed an average of only 12-18 ha annually. In contrast, the private tractor owners could plow up to 240 ha per tractor per year (Stryker et al. 1990 p. 116).

Facing a series of economic and political crises that had pushed the country's economy to the edge of a total collapse, the Government of Ghana started the Structural Adjustment Program (SAP) in 1983, earlier than most other 
African countries that underwent similar IMF- and World Bank-guided reform processes. The significant cuts in the government's overall budget and support to state interventions, including various agricultural subsidy programs, led to the eventual discontinuation of the government-supported THS schemes. With the huge devaluation of domestic currency, prices for imported capital goods, including tractors, became considerably high in terms of local currency and few large farmers could afford to buy such imported capital goods. These two factors led to a fall in the level of agricultural mechanization following the SAP in the 1980-1990s (Aryeetey and Baah-Boateng 2007). This is similar to what occurred in many African countries, including Nigeria as described in this book. The decline in mechanization in the 1980-1990s was a correction from the unsustainable level of mechanization in the 19601970 s created by the government's direct interventions and other distortionary policies. While the 1970 s were characterized by substantially higher levels of public expenditure in agriculture, including spending on mechanization, most direct interventions were expensive and had limited effects on overall agricultural performance (Akoto 1987). This suggests that the early mechanization push in the 1960-1970s was a failure.

\section{The Emergence of High Demand for Mechanization in Ghana}

The failure in the early push for tractorization by African governments has led agricultural economists to emphasize the importance of demand-side factors in mechanization. In the 1980s the lag in mechanization was attributed mainly to the slow progression of agricultural intensification from long fallow to permanent agriculture. By examining the existing farming systems in Africa carefully, Pingali, Bigot, and Binswanger (1987) provided a formal analysis on the main reasons for the slow progress of agricultural mechanization in Africa. The authors argue that the slow transition from hand hoes to mechanized plowing can be explained by the lack of evolution in farming systems. In long- and medium-fallow systems, tree stumps are present in the fields because they have not had time to rot away. Therefore, the plow cannot be used in these systems until they have progressed to the stage of short fallow or permanent agriculture. When the systems move from long or medium fallow to short fallow or permanent agriculture, one reason for the switch in technology is that as fallows get shorter, grassy weeds and hardened soils become harder to overcome with hand hoeing, making animal or tractor plowing more attractive. 
One theory, developed based on Hans Ruthenburg's (1980) historical analysis of the evolution of tropical farming systems, predicts that farming communities will only adopt draft animals or tractors for land preparation once their land use intensity reaches a critical threshold. Ruthenburg measured land use intensity as the ratio of the harvested area to the total agricultural area (cropland plus fallow land). He called this the R-value and concluded that it must exceed 33 before mechanization of land preparation would take hold. This is equivalent to when the average fallow period has been shortened to less than two years for each year of cultivation.

Diao et al. (2014) calculate annual R-values for Ghana over the period 1961 to 2011 (Figure 11.1). While still relatively land-abundant, land use intensity has increased since the late 1990s in Ghana. Until the late 1990s, Ghana had low R-values, during which time there was little evidence of demand for tractor mechanization. From the late 1990s onward, however, the R-values have permanently risen above the threshold of 33, reaching 40 to 43 in the late 2000s. While this highly aggregated data fails to capture important regional variations, it does suggest that farming systems and land use intensity have changed significantly in Ghana since the late 1990s, permitting more mechanization.

However, Binswanger and Savastano (2016) notice that while rising population density and improved market access have transformed a large share of African agriculture to permanent cropping-for example, in Ethiopia, Kenya, and the Savannah zones of West Africa-only in a few of these areas has mechanical tilling been adopted, either via animal draft or via tractors. Therefore, Binswanger-Mkhize (2017) argues that the farming systems explanation no longer seems to be a sufficient explanation for the slow progress of mechanization in some African countries.

Indeed, Ruthenburg's R-value as a measure of land use intensity seems to be only a necessary but not sufficient condition for assessing the demand for mechanization. Another relevant theory from the literature is the induced innovation theory, which essentially predicts that mechanization being a labor-saving technology means that demand will develop once labor becomes sufficiently costly relative to capital and other purchased inputs (Hayami and Ruttan 1970, 1985; Binswanger and Ruttan 1978; Pingali, Bigot, and Binswanger 1987). This typically happens after a country has reached a point in its economic transformation where the number or the share of workers remaining in agriculture begins to decline and the land-labor ratio increases. For field crops, this usually leads to farms getting bigger and as there is greater scarcity of labor relative to land, farmers have an incentive to adopt laborsaving technologies like mechanization. 
FIGURE 11.1 R-value measure of farming system evolution in Ghana, 1961-2014

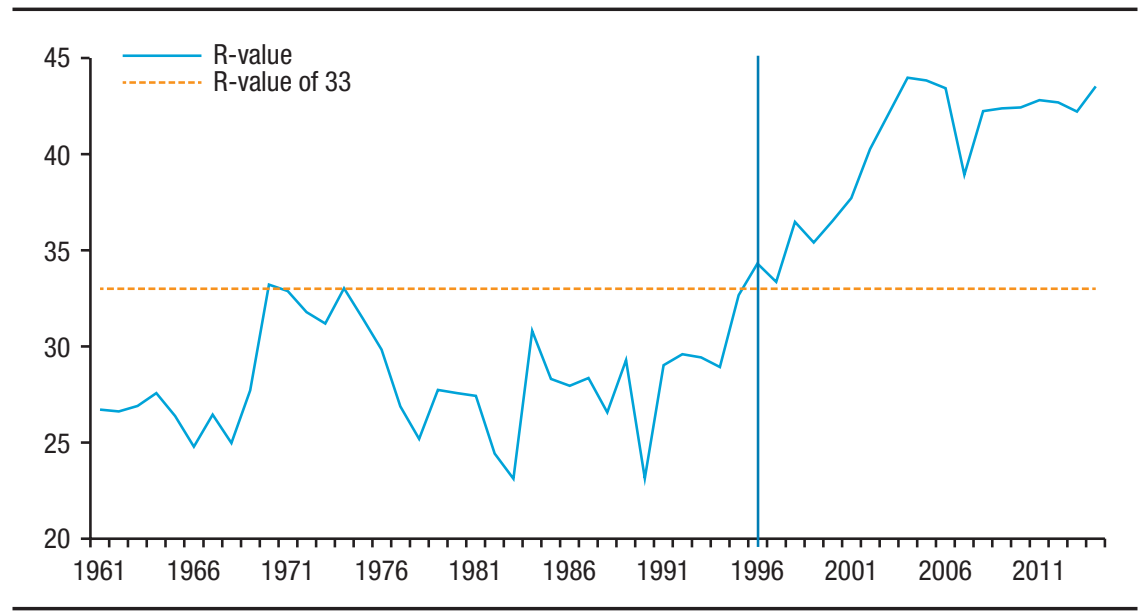

Source: Compiled from FAO data.

\section{Land-Labor Ratio}

Unlike many African countries, Ghana is still a relatively land-abundant country; as shown in Table 11.1, the average cropped area per rural person actually increased by 11.8 percent between 2000-2010. This happened despite continued population growth, because rapid urbanization has pulled many workers out of agriculture on a full- or part-time basis, and changing marketable opportunities have simultaneously led farmers to increase their cultivated areas. However, Table 11.1 shows that there are important regional differences in these changes. Looking across regions, there is an inverse relationship between increases in the cropped area per rural person over 2000-2010 and population density. For example, Brong Ahafo region experienced the largest percentage increase in its cropped area per rural person (52.5 percent) and was also among the regions with the lowest population density in 2010. At the other extreme, the Greater Accra region experienced a 38.8 percent decline in its cropped area per rural worker and had the highest population density after Central region in 2010. Moreover, the regions that experienced the largest increases in their land-labor ratios are the most important regions in terms of national food crop production (Table 11.1).

\section{Farm Size}

One consequence of an increasing land-labor ratio has been that farms have grown larger where land is relatively abundant. The expansion of farm size 
TABLE 11.1 Crop area per rural person, by region, 2000 and 2010

\begin{tabular}{lccccc}
\hline & $\begin{array}{c}2010 \\
\text { Region }\end{array}$ & $\begin{array}{c}\text { Rural population density } \\
\text { (persons/(km²) }\end{array}$ & $\begin{array}{c}\text { 2010 share in } \\
\text { national food crop } \\
\text { area (percent) }\end{array}$ & \multicolumn{2}{c}{ Crop area per rural person (ha) } \\
\cline { 5 - 6 } & 57 & 6.7 & 2000 & 2010 & Percent change \\
\hline Western & 118 & 7.0 & 0.20 & 0.18 & -6.7 \\
Central & 117 & 0.3 & 0.06 & 0.23 & 12.3 \\
Greater Accra & 77 & 14.1 & 0.34 & 0.35 & -38.8 \\
Eastern & 68 & 5.9 & 0.14 & 0.16 & 4.0 \\
Volta & 77 & 12.8 & 0.24 & 0.26 & 7.7 \\
Ashanti & 32 & 18.5 & 0.35 & 0.54 & 52.5 \\
Brong Ahafo & 25 & 16.1 & 0.33 & 0.35 & 7.0 \\
Northern & 32 & 10.6 & 0.58 & 0.68 & 16.8 \\
Upper West & 94 & 8.0 & 0.41 & 0.36 & -12.6 \\
Upper East & 51 & 100.0 & 0.28 & 0.31 & 11.8 \\
National & & & &
\end{tabular}

Source: Diao et al (2014).

is one of the most important ways for farmers in Ghana to respond to the increased market demand for food crops from urbanization and growth in household income, and recent improvements in market access have made it possible for many farmers to switch to more market-oriented production.

Nationally, there has been an increase in the share of medium-sized (2-20 ha) farms at the expense of small (less than $2 \mathrm{ha}$ ) farms, and medium-sized farms now account for half of all farms (Table 11.2). This change masks important differences at regional levels. In the northern regions (comprising the savannah and transition zones), medium-sized farms have surged ahead and now account for 60 percent of all farms. However, there has been a reverse trend in the south (comprising the forest and coastal zones), where the share of medium-sized farms has actually declined (from 44.7 percent to 41.1 percent) and the share of small farms has increased.

Generally, for medium-sized farmers to further expand their farm size, they depend on mechanization for land preparation. Moreover, while they are more likely to become owners of tractors, they cannot fully utilize the capacity of the tractors on their own farms. Thus, the increasing farm sizes and tractor ownership seem to reinforce each other from both demand and supply sides of mechanization. That is, owning a tractor might encourage the farmers to cultivate a larger piece of farmland, which is a demand-side factor from mediumsized farmers for mechanization. At the same time, cultivating a large land size 
TABLE 11.2 Changes in the farm size distribution, 2005/2006 and $2012 / 2013$

\begin{tabular}{lccc}
\hline $\begin{array}{l}\text { Region/year } \\
\text { National: }\end{array}$ & $\begin{array}{c}\text { Small } \\
(<2 \text { ha })\end{array}$ & $\begin{array}{c}\text { Medium } \\
(2-20 \text { ha })\end{array}$ & $\begin{array}{c}\text { Large } \\
(>20 \text { ha })\end{array}$ \\
2005/2006 & & & \\
2012/2013 & 53.3 & 44.7 & 1.9 \\
North: & 49.3 & 49.8 & 0.9 \\
2005/2006 & & & \\
2012/2013 & 44.3 & 52.5 & 3.2 \\
South: & 38.6 & 60.0 & 1.4 \\
2005/2006 & & & \\
2012/2013 & 53.3 & 44.7 & 1.9 \\
\hline
\end{tabular}

Source: Authors' calculations using GSS (2014).

Note: South $=$ Coastal + Forest zones; North $=$ Savannah + Transition zone .

might also encourage these farmers to procure a tractor and participate in the THS, thereby increasing the supply of mechanization.

\section{Urbanization}

Urbanization is an important factor driving increased demand for mechanization because growing market demand for agricultural products is often a key driver of intensification. In Ghana, intensification as a whole, and mechanization in particular, appears to be fairly correlated with market access, measured by travel time to large towns and proximity to roads (Cossar 2015). Changes in dietary structure associated with urbanization lead to increased demand for cereals, which generally have higher labor requirements than roots and tubers and are more conducive to mechanization (Nin-Pratt and McBride 2014).

Ghana has rapidly urbanized in the past two decades and since 2010 more than half of the total population lives in urban areas. There has been substantial migration of workers from rural to urban areas alongside considerable employment growth in the rural nonfarm economy, which have together led to a decline in the share of workers remaining in agriculture to about 40 percent of total employment in recent years. However, national statistics mask considerable spatial heterogeneity within Ghana. Until recently, a majority of its labor force was still working in agriculture, particularly in northern Ghana. However, because of low population density in the north, farm sizes 
tend to be larger there than in the south (Table 11.2). Moreover, because the north corresponds closely to the savannah and transition agroecological zones, its agriculture is dominated by field crops (particularly cereals) that are suitable for tractor land preparation, instead of permanent tree crops grown in the forest zone in the south that are not suitable for tractor operation. Indeed, in recent years, northern Ghana has increasingly become a food basket, providing maize and rice to urban markets throughout the whole country.

\section{Rising Rural Wages}

Urbanization also creates nonfarm jobs in both urban and rural areas, putting an upward pressure on rural real wage rates and hence creating demand for labor-saving technologies like mechanization. Mechanized plowing significantly reduces the labor required for land preparation and, to a lesser extent, reduces the labor required for weeding and harvesting (Pingali, Bigot, and Binswanger 1987). When hired labor is a major source of agricultural labor in certain farming activities - for example, in land preparation and harvestthe bottleneck effect of seasonal labor shortages increasingly becomes a factor prompting farmers to switch to mechanized services where they are available. The demand for mechanized service is further boosted when rural hired labor represents a relatively large share of production costs and becomes more expensive. Under such circumstances, even small farmers begin to demand mechanization technology. Recent economic structural changes have increased job opportunities in the rural nonfarm economy, and many family members of smallholder rural households are participating in nonfarm economic activities (Diao et al. 2014), which puts an upward pressure on rural wages.

Rising rural labor costs in both the north and south are one of the most important emerging factors in recent years to explain the accelerated demand for mechanization in Ghana. Table 11.3 provides agricultural wages for different types of farming activities at the national level and annual average rates across regions from 1991 to 2012. At the national level, agricultural real wages have grown by almost 7 percent per year over the period. At the regional level, agricultural wages have grown at a similar pace across regions in both the north and south. There are some exceptions to this; for example, male wages for land clearing in the Eastern region grew at about half the national rate.

While mechanization for land preparation is not necessarily a productivity-enhancing technology (Pingali, Bigot, and Binswanger 1987), reducing the dependency on hired labor improves farmers' control over the timing of agricultural operations. In semi-arid areas of Ghana with few days of rainfall, or in areas with bimodal rainfall that practice multiple seasons 
TABLE 11.3 Agricultural wages and annual average growth rate in Ghana, 1991-2012, by type of work

\begin{tabular}{lccc}
\hline Year/region & Men clearing & Women harvesting & Men harvesting \\
\hline \multicolumn{2}{l}{ Level of national average agricultural real wage (new Cedis, deflated by CPI) } \\
1991 & 1.18 & 0.94 & 1.11 \\
1998 & 1.39 & 1.03 & 1.35 \\
2005 & 2.30 & 1.84 & 2.38 \\
2012 & 4.55 & 3.60 & 4.24 \\
Average annual growth rate (1991-2012) & & \\
Western & 10.82 & 7.69 & 6.56 \\
Central & 6.10 & 6.80 & 6.66 \\
Volta & 7.52 & 7.42 & 7.31 \\
Eastern & 3.22 & 5.73 & 5.27 \\
Ashanti & 6.29 & 7.79 & 7.93 \\
Brong Ahafo & 5.41 & 4.87 & 6.78 \\
Northern & 5.26 & 4.66 & 3.25 \\
Upper East & 6.80 & 6.19 & 6.47 \\
Upper West & 6.46 & 5.00 & 3.55 \\
National & 6.62 & 6.57 & 6.60 \\
\hline
\end{tabular}

Source: Authors' calculation using multiple rounds of household surveys (GSS 2014). Note: $\mathrm{CPI}=$ consumer price index.

of cropping, seasonal labor bottlenecks can have impacts on productivity. In Northern Ghana a two-week delay in planting can lead to a 30-55 percent loss of yield (Houssou, Diao, and Kolavalli 2014a).

Putting together the agroecological factors and dynamics of recent economic transformation, it is reasonable to believe that demand for mechanization is rising and is no longer a constraint for the development of mechanization in Ghana. However, because agricultural production is largely influenced by agroecological conditions, both potential demand and adoption of mechanization often exhibit substantial spatial variation within a country. Existing demand for mechanization is often first concentrated in certain areas, such as those where farm size is relatively larger than the national average (for example, Northern Ghana) or those that are highly urbanized with small farm sizes (for example, Greater Accra areas). The recent Labor Force Survey conducted in 2015/2016 in Ghana shows that while just one third of crop-growing households practice mechanized agriculture using farm machinery (primarily for plowing), the adoption rate is as high as 88.5 percent in the 
Upper West region and 76.9 percent in the Greater Accra region (GSS 2016). On the other hand, there is relatively low demand for mechanization in the parts of the southern forest zone that have dominant permanent tree crops and tree stump issues. The adoption rate of mechanization is in the range of 2-10 percent in these forest zone regions (GSS 2016). In Ghana's Upper East region, the adoption rate of mechanized agriculture is also low at 18 percent (GSS 2016), mainly because of a tradition of using animal traction (Houssou et al. 2013b) and the predominance of smaller farms. It should also be emphasized that mechanization adoption varies significantly not only across regions in Ghana but also within regions across districts (Houssou et al. 2015). In Brong Ahafo region, for example, mechanization has been widely adopted in the maize-dominant grassland areas, but it is not the case in tree cropdominant places or in the forest areas (Cossar 2015). Clearly, a nationwide push for mechanization by the government should be avoided given such heterogeneity in the demand for and suitability of mechanization across areas.

Observations from field visits of IFPRI researchers in the savannah zone of Ghana in 2012-2013 also confirm the emerging high demand for mechanization, including from small famers. During their field visits, many small and relatively large farmers were interviewed, as well as tractor owners and users of hiring services. Everywhere they went, the researchers heard complaints from farmers about the lack of tractor services to meet their demand, and there was no single case in which a tractor owner complained of a lack of adequate demand for his or her services. Farmers who hired tractor services reported that they often had to approach more than one tractor owner before securing services to plow their field. Farmers who hired out their tractor services reported that they never have any concern for lack of consumers, and during land preparation season, they are often inundated with requests for services. With evidence that tractor ownership has increased in recent years, farmers hiring tractor services reported that it is becoming easier in some locations to secure plowing and maize threshing services, as compared with the past (Diao et al. 2014).

\section{The Supply of Agricultural Mechanization in Ghana}

The supply of mechanization includes manufacturing and importation of machines, mechanized service provision to farmers, fabrication and distribution of attachments and spare parts, and machinery repair and maintenance services. In Ghana, there are currently two parallel supply channels for 
agricultural mechanization services: the private sector's supply system characterized by farmer-to-farmer hiring out services, and a government-sponsored Agricultural Mechanization Services Enterprise Center (AMSEC) program. We consider each in the two subsections that follow.

\section{Private Sector-Led Mechanization}

The private-sector supply chain is well-developed and combines machinery importers, mechanized service providers (mostly medium-scale farmers), and repair and maintenance shops. The private sector has operated in Ghana's mechanization business for more than two decades, and it has scaled up in the last decade. Other than benefiting from an import tariff exemption that applies to all agricultural machinery imports, the private sector supply chain receives no other support from the government. The scale of the private sector is significant; while the government imported about 3,000 new tractors and 300 power tillers over 10 years, a similar (and possibly greater) number of used tractors were imported by private importers in the same period (CEPS 2012). The share of used tractors in total imports has increased substantially since 2010 (Figure 11.2), suggesting considerable and growing demand for affordable tractors in the private sector.

Private importers are predominantly small-scale businesspeople who have well-developed import channels in Europe for secondhand tractors, and tractor importation is typically only part of their business. This diversification enables them to spread their risks and to smooth out the seasonal nature of the demand for tractors. Their clients are mostly medium- and large-scale farmers, who want to buy imported secondhand tractors (USAID/ACDI-VOCA 2013). As in the automobile market, used tractors have a price advantage over new tractors of the same brand and are typically even less costly than the subsidized new machines imported for the government.

Secondhand tractors are attractive to farmers not only because they are more affordable, but because they can obtain tractor brands of their own choice. Moreover, since the private sector has operated in the tractor import business for many years, the spare parts for the brands they import are available in most locations at reasonable prices. By contrast, the brands of new tractors imported by the government keep changing, and spare parts for them are harder to obtain.

Medium- and large-scale farmers are the main buyers of secondhand tractors from private importers, and they are also the main providers of mechanized services to other farmers. For most of them, hiring out tractor services after they have plowed their own land is an important way to justify the 
FIGURE 11.2 Tractor imports in Ghana, 2003 to 2012

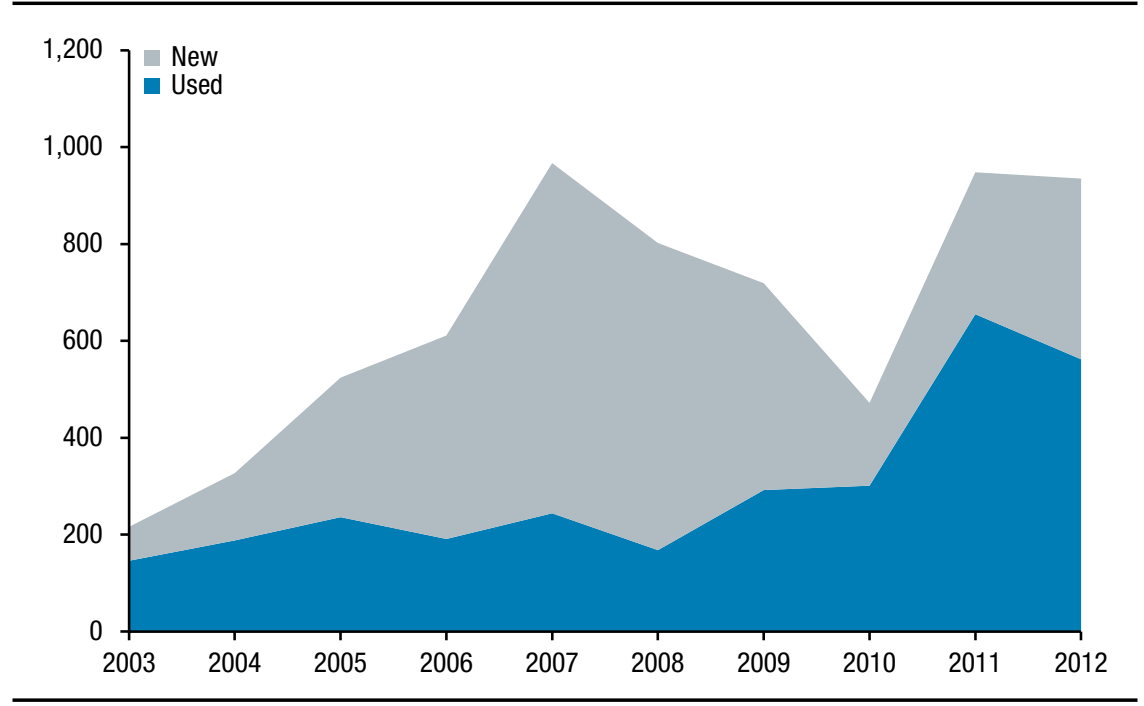

Source: CEPS (2012).

substantial lump sum investment cost involved (Houssou, Diao, and Kolavalli 2014a). The 2013 IFPRI/SARI survey found that for tractor owners the ratio of their numbers as service providers to the number of service users is 1 to 100-120 in 2012; on average, a medium-scale farmer who owns a tractor provided hiring services to $100-120$ other farmers, of which almost half are small-scale farmers with land area less than 2 ha (Houssou, Diao, and Kolavalli 2014a). On the other hand, almost half of the surveyed smallscale farmers hire tractor services for plowing; nearly all of these services were sourced locally and most were provided by other farmers (Benin 2013). Because of the dominant role of medium- and large-scale farmers in providing tractor services, the market for land preparation services is competitive. One outcome is that farmers in different locations are paying similar prices for plowing services (Benin 2013).

\section{Market Failures in Agricultural Machinery Investment}

Tractors are expensive, and like other indivisible lump sum investments, owning a tractor has an investment risk associated with the uncertainty about the returns to investment. While demand for mechanization appears to be growing among farmers in Ghana, such demand does not necessarily lead to adequate supply responses. Market failures could slow down the private sector's supply response to the increased demand for hiring services for mechanization. 
While the private sector has operated in Ghana's mechanization business for more than two decades, up until the early 2000s few farmers in Ghana owned tractors and most of those who did were large-scale. The farmer-tofarmer hiring services are a rather new business in many areas of the country. Like an infant industry, the market for such hiring services is in its early development stage, and the uncertainty in such markets for potential tractor owners is whether local demand for hiring services is large enough to make their investment profitable. The 2013 IFPRI/SARI survey found that 85 percent of tractor owners were the consumers of hiring services for about 10 years on average before they decided to purchase their own tractors; this exposure to the service market gave them a better understanding of the market (Houssou, Diao, and Kolavalli 2014b).

Migratory service provision is rare in Ghana. While there are different agricultural seasons in the north and south, only about one fifth of surveyed tractor owners migrate between the two regions and most of these owners are clustered in one district (Chapoto et al. 2014). While it is unclear why more owners do not take advantage of the different seasons, possible explanations include uncertainty over demand, information asymmetries in other areas, and lack of transport infrastructure. Risk and uncertainty will likely decrease as the hiring services market becomes more established and more private owners participate, but currently the supply response is expected to lag behind demand as individuals providing hiring services require a period of learningby-doing. In China however, county-level governments have facilitated the process for migratory service provision by helping machine owners overcome the risks caused by coordination failures and information asymmetries (Yang et al. 2013).

Market failure caused by the uncertainty in the service hiring market is magnified by the lack of accessible credit in the financial market for such investments. In Ghana, tractor owners depend on their own savings for machinery investment. Only 3.4 percent of surveyed medium-scale farmers who owned tractors obtained any loan for their purchases (Chapoto et al. 2014). Accumulation of the large amount of money needed to purchase tractors takes time. Land tenure traditions also contribute to this problem. In Ghana, land has historically been communally owned. Such traditional land tenure systems help the country avoid land concentration in the hands of a small number of large owners, but also mean that individual farmers cannot use land as a personal business asset with which to secure loans to purchase agricultural machinery. Interest rates for existing commercial loans are also too high to attract borrowers for agricultural machinery investment. 
Consequently, the supply of hiring services tends to be concentrated in the areas where there are large- and medium-scale farmers who can afford the investment in machines, and the supply response in other areas is slow to meet the rapidly growing demand for mechanization.

Investment risk is also associated with the cost of a tractor. Besides the low-cost, relatively affordable secondhand tractors, there is almost no available small agricultural machinery that is both affordable and suitable for local conditions. This is an important constraint to investing in a tractor for many farmers. In developing countries in Asia, on the other hand, tractors come in a wide range of sizes, horsepower, and prices. Power tillers and low-horsepower, small four-wheel tractors have been manufactured in China, India, and some other Asian countries. Prices for these smaller machines are affordable for many small- and medium-scale farmers in Asia (Diao et al. 2014). Farmers in Ghana commonly favor large and powerful tractors; the average horsepower of tractors in Ghana ranges from 60-80, while smaller tractors popular in Asian countries fall in the range of $20-40 \mathrm{hp}$ (World Bank 2014).

In Ghana, like in other African countries, the availability of smaller agricultural machinery-including small tractors that are relatively affordable for small-scale farmers and suitable for African soil conditions-is limited. Power tillers are used in irrigated paddy rice fields for plowing in the Kpong irrigation scheme in Eastern region (Takeshima et al. 2013). But with a low level of irrigation in the country, the potential for adoption of power tillers is low. Without affordable and suitable smaller tractors, the market alone is unlikely to create enough incentive for would-be suppliers of mechanization services to meet demand. While further research is needed to fully understand why smaller tractors have not been widely adopted in Ghana, here we explore a few reasons for the market failures in mechanization.

\section{LIMITED KNOWLEDGE AND INFORMATION ABOUT SMALL MACHINERY}

The early push for mechanization through state-run mechanization service centers in the 1960-1970s exposed Ghanaian farmers mainly to large tractors; in fact, many large tractors imported during that period are still operated and owned by large-scale farmers today. There is little knowledge among farmers and would-be-suppliers of mechanization services about different types of mechanized technologies, such as the returns to tractors of different amounts of horsepower, the merits of small machinery such as hand tillers, or the appropriate use and handling of different machines. Similarly, would-be importers need to be aware of various engine and equipment sizes and their potential uses in order to assess potential demand and business opportunities 
related to smaller mechanized equipment. Secondhand tractors imported from Europe by private traders are all large, and the existing supply chains for spare parts often cater to the few brands of large tractors already popular in the country. While knowledge about smaller machine availability and performance will increase as information and evidence spreads, until then importers, farmers, and potential tractor owners will be unlikely to change their preference for larger machinery.

\section{LACK OF SMALLER ENGINES FOR AGRICULTURAL MACHINERY SUITABLE FOR AFRICAN CONDITIONS}

It is not clear whether smaller engines for agricultural machinery that have been widely adopted in Asian countries are suitable for African conditions. In most areas of Africa that are dependent on rainfall for crop production, the tropical soils are heavy and highly compacted. In many areas of Ghana, we were frequently told that current small-scale tractor engines are not suitable for local conditions because they are not powerful enough for land preparation if soils are very dry before the rains. Additional research and development $(\mathrm{R} \& \mathrm{D})$ investment in designing smaller engines for locally-appropriate equipment appears necessary. For such investments, the social returns are often larger than the private returns to firms, when the technology can be easily copied by other firms. The existence of this potential positive externality may require incentivizing private investment.

\section{LIMITED OPTIONS FOR MULTIPURPOSE TRACTORS}

Plowing is a seasonal activity and while tractor use for plowing reduces the risk associated with delays in land preparation and crop planting, investment in a tractor is unlikely to be profitable for small-scale farmers without using the tractor for other purposes. In fact, the use of tractors can be extended to many functions beyond land preparation, such as using the tractor's engine to power threshing machines or water pumps. This multifunctionality is often an important condition for achieving profitable utilization rates for tractors. The hiring services that can be widely disseminated among many farmers in Asian developing countries are strongly associated with the multifunctionality of tractor use, especially in the early stage of mechanization (Diao et al. 2014). In Bangladesh, for example, it was the removal of import restrictions on small, cheap, diesel engines from China that first led to the rapid development of mechanized small-scale irrigation. When the restrictions on Chinese-made power tillers were lifted later, they were immediately used to power shallow tubewells for irrigation. Researchers argue that the synergy between power 
tillers and irrigation led to the rapid mechanization in Bangladesh (Biggs and Justice 2015).

However, in many parts of Ghana irrigation options are limited by lack of suitable and affordable small-scale irrigation technology and limited knowledge of how to utilize available water resources such as ponds, creeks, and shallow water resources for irrigation. This lack of technology and information significantly restricts opportunities for utilizing a tractor's power. Another common use of tractors is transportation. When Asian countries started to adopt power tillers for land preparation, the machinery was also the lowestcost transport equipment available in rural areas. While farmers in Ghana have started to use tractors as engines for maize threshing machines and occasionally for carting crops from the field, motorized tricycles (both imported and locally assembled) are currently much more popular for transporting goods and people; they also cost less and use less energy than most large tractors. As a result, tractor use is largely limited to plowing. The survey shows that 90 percent of the revenues generated from tractor service provision in Ghana are from plowing services (Houssou et al. 2013). In addition, lack of knowledge of good practices for land preparation in areas without a tradition of animal traction further limits tractor use. Ghanaian farmers often prefer a one-time plowing and are reluctant to pay additional fees for a second plowing or for leveling and harrowing, which are common practices in East African areas with animal traction. The survey shows that only a fraction of tractors was used for second plowing or for harrowing, although the attachments for harrowing are imported by the government at subsidized prices.

\section{Ghana's Agricultural Mechanization Services Enterprise Center (AMSEC) Program}

The existence of market failures leads to the government's concern that supply-side issues may be constraining mechanization uptake, especially among smaller farms. With this in mind, in 2007 the government started to directly engage in the importation and subsidization of tractors and has established about 90 Agricultural Mechanization Services Enterprise Centers (AMSECs) around the country (Diao et al. 2014). While the intention of such a government program is to address market failures, the analysis below indicates that the AMSEC model has not overcome the market failures discussed above; in fact, such state-supported professional hiring services make less efficient use of tractors than do nonsubsidized farmer-to-farmer hiring services (Oluka 2000; Kienzle, Ashburner, and Sims 2013; Takeshima et al. 2015). 


\section{STATE-INFLUENCED TRACTOR IMPORTS}

The main source of funding for AMSEC is through concessional loans received by the government, primarily from various emerging economies such as Brazil, China, and India. Such concessional loan agreements require that Ghana imports tractors from the lending country. Therefore, different loan agreements have brought in different brands of tractors from different countries. In theory, the government does not directly import any tractors, but uses private agents to act on its behalf. However, the government selects the private agents and they have no say over the type of machinery to be imported or ability to negotiate prices, both of which are determined as part of the loan agreements. The import of Farmtrac tractors is a good example of this process and its problems. After receiving a concessional loan for tractor imports in 2007 and 2008 from the Export-Import Bank of India, the government selected a local company as its import agent. The company imported 500 Farmtrac tractors from India in 2007 and 2008, but had no say in the selection of the Farmtrac brand, the tractor models chosen, or the import prices. Expecting their business to continue with the government, the company constructed a large warehouse and built up stocks of spare parts with its own money. However, in 2009 the government entered into a new concessional loan arrangement with the Indian government to import John Deere machinery manufactured in India and a new local company was selected as the government's importing agent. This undercut the company importing Farmtrac tractors; not only could they no longer import subsidized tractors from India, but their own investment in building up a stock of spare parts was devalued. Similar one-time arrangements have been made recently for importing Mahindra tractors from India and other brands from China, Brazil, and other countries.

In discussing the market failures that lead to the lack of small-scale engines for agricultural machinery suitable for African conditions in the previous subsection, we pointed out that additional R\&D investment in designing smaller engines for locally-appropriate equipment appears necessary. The manufacturers in tractor-exporting countries have the best capacity for such R\&D and may be able to develop smaller products and new technology suitable for Ghana. However, such investment will not be attractive if the current brands and models can be easily sold to Ghana through the concessional loan agreements between Ghanaian and donor country governments. In fact, instead of mitigating this market failure, importation under the current concessional loan agreement discourages the incentives for the private sector in donor 
countries to conduct $\mathrm{R} \& \mathrm{D}$ investment, which is necessary for developing affordable and suitable small tractors for Ghana and other countries in Africa.

\section{GOVERNMENT-SELECTED “PRIVATE” ENTITIES AS AMSECS}

In order to avoid direct government management of mechanization services, private agents are selected by the government to own and operate the machinery services centers. The first group of 12 AMSECs was established between 2007-2008 and each center was given a package of seven tractors with basic attachments by the government. The centers paid only 20 percent of the already-subsidized price of the tractors, with the outstanding amount to be paid off over four years without interest. A further 77 AMSECs were established in 2009-2010 through a similar process and under the same financing arrangement. Given that the subsidized tractor prices are well below market prices to begin with, the generous financial arrangements seemingly make AMSECs a lucrative and attractive business and the government has not had any difficulties in attracting applicants. In fact, there have been so many applicants that the government has had to turn most down; however, the criteria for selection are not given. This raises concerns about possible rent-seeking behavior. Obviously, the establishment of the AMSECs through this less than transparent process is not only unlikely to overcome the market failures discussed above, but also risks creating a government failure and distorting the mechanization services market.

\section{DIFFICULTIES WITH THE SPECIALIZED TRACTOR SERVICES}

The AMSECs were designed to provide specialized tractor services to the local market without adequate consideration of whether this is would be profitable. Unfortunately, it turned out that many AMSECs were not profitable and have defaulted on their debt repayments, leaving the government responsible for the repayment of concessional loans.

Houssou et al. (2013a) have demonstrated why tractor hiring alone is not profitable for many AMSECs. Based on subsidized tractor prices, actual operational costs in Ghana, and an assumed 10 percent capital depreciation rate, they calculate that a minimum of 287 ha must be plowed per tractor in order for the net profit from plowing services to be comparable to the interest earnings from a similarly-sized savings deposit in a bank account-a necessary condition for tractor renting to break even. Using survey data, Houssou et al. (2013a) show that few AMSECs plow sufficient acreages to be profitable. An important reason is that the plowing season is too short to enable tractors to plow larger acreages within the localities that each AMSEC serves. The plowing season is as short for the farmers as it is for tractor owners. The low price 
of secondhand tractors owned by farmers is just one reason that they make a potentially profitable investment, but for a medium-scale farmer the total returns to investment include not only preparing their own land, but also revenues earned from providing hiring services.

One way to increase the utilization of tractors is through seasonal migration to different regions with complementary plowing seasons. South Ghana, for example, has two cropping seasons while the north has one; this difference could in theory be exploited by mobile tractor service providers to increase the number of operational days per tractor (Houssou et al. 2013a). In practice, there is little evidence of any of the AMSECs attempting to be regionally mobile, although there is evidence that some private tractor owners are doing so.

Another possible way to make AMSECs more profitable would be for them to diversify beyond plowing and offer a wider range of mechanization services. As discussed above, limited options for using tractors for multiple purposes is also a constraint for the private sector's investment in tractors. The survey by Benin et al. (2012) showed that AMSECs did not do better. In 2010, only 38 of 136 surveyed machinery services firms provided services other than plowing, and even these firms still got 80-90 percent of their revenue from plowing. As discussed, the lack of knowledge of good land preparation practices in areas without a tradition of animal traction limits tractor use. So far there has not been much demand for additional services in Ghana; farmers often prefer one-time plowing and are reluctant to pay additional fees for a second plowing or for leveling and harrowing, which are a common practice in areas of East Africa with animal traction. There is a role for the government to play in addressing this knowledge gap, but AMSECs do not currently seem to have better capacity to do this than individual farmers providing hiring services or private importers, both of whom have more experience in this business. Furthermore, experience in some other countries has shown that demand for mechanized services other than plowing typically develops in parallel with innovation in the design and adaptation of other kinds of tractor implements and machines tailored to the niche needs of specific groups of farmers or localities (Diao et al.2014). This kind of innovation is much more likely to arise in the private sector than with the government-sponsored AMSECs.

\section{Conclusions}

Ghana's farming systems have undergone significant changes in the last 30 years, which have led to a growing demand for mechanization. So far, the 
demand has been primarily for tractor plowing and this need is being met by parallel supply systems: the heavily subsidized, state-interventionist AMSEC program; and a well-developed, private-sector supply chain of importers, machinery service contractors (mostly farmers), and repair and maintenance shops. There are market failures that have led to inadequate supply responses to the demand of small farmers for mechanization. The AMSEC model recently promoted by the government has not overcome such market failures, and does not seem to be viable in its present form. Continuation of the AMSEC program in its present form will only add to the financial burden on the government and possibly foster rent-seeking behavior among government-selected agents who import tractors or run the AMSECs. Rethinking the role of government in facilitating the supply response of mechanization leads to the following policy recommendations:

- Instead of promoting the government-sponsored AMSEC model in Ghana, attention should switch to the private sector-led supply chain, and in this regard, the farmer-to-farmer tractor hiring services merit more assessments to better understand the broad support needed from government for their further development. These recommendations are in line with experiences described in many of the Asian chapters, in which informal-sector, farmer-to-farmer tractor hiring services have been the driving force, rather than government-designed schemes.

- Research and development focusing on affordable and smaller agricultural machinery suitable for Africa's local conditions should be an important component of agricultural technological innovation programs for the government and development partners. The R\&D activities that aim to generate knowledge of the benefits of different types of mechanized technologies can be jointly conducted with researchers from other countries. Regulatory policies in testing, certification, and licensing of different types of machinery need to be revisited to effectively mitigate information asymmetries without substantially raising the costs of machinery.

- Agreements with donor-country governments' concessional loan arrangements should pay more attention to the suitability and affordability of different types of agricultural machinery. Both the Ghanaian government and donor countries' governments can facilitate technological development and knowledge transfer under such agreements and promote smaller-scale engines of agricultural machinery suitable for local conditions. This can be done through collaboration and partnership between technicians, 
engineers, and other experts from donor countries with counterparts in Ghana, including tractor users and importers.

- Reform subsidies by avoiding arbitrary selection of recipients and types of subsidized machinery and increasing transparency to eliminate rentseeking behavior. Several of the Asian chapters described how subsidies have often been less distorting if they are applied to a wide range of equipment regardless of brands, while simultaneously reducing the rates of subsidies has avoided fiscal burden. The effectiveness (or lack thereof) of different modalities of temporary subsidies, including direct subsidies to farmers and interest rates rather than price subsidies, should be thoroughly analyzed.

- Encourage private financial institutions' agricultural machinery lending. Also, within the current land tenure system, experiment with formal land use rights that would allow land to be used as collateral for loans, as described in the Myanmar chapter. Through broad engagements with the private sector on both the demand and supply sides of private financing, explore any practical approach, with necessary government support, and promote the financial market development in agricultural machinery investment.

- Experiment with conservation farming with minimum tillage requirements tailored to local conditions. While there are opportunities for technological leapfrogging in some areas of Ghana, substantial R\&D is needed, from data collection and analysis of detailed soil maps to location-specific recommendations for proper practices.

- Government should encourage engineering departments in universities and polytechnics to provide technical support for design or adaption of more simple machinery suitable for local conditions, as has been done in several Asian countries including India, Sri Lanka, and Thailand. While local fabrication exists in Ghana for simple machines, like other small businesses in the country, these small firms operate on their own without financial or technical support from the government. Government can facilitate collaboration with experts on small agricultural machinery from other developing and developed countries and encourage them to engage in knowledge and suitable technological transfers from abroad to Ghana.

- Low-cost outreach courses for mechanics and tractor owners in rural areas to improve their knowledge of tractors and other machinery and 
repair skills could be considered as part of training programs supported by donors and provided by local or international technical institutes.

\section{References}

Abdulai, A., and W. Huffman. 2000. "Structural Adjustment and Economic Efficiency of Rice Rarmers in Northern Ghana." Economic Development and Cultural Change 48 (3): 503-520.

Akinola, A. 1987. "Government Tractor Hire Service Scheme as a Tractorization Policy in Africa: The Nigerian Experience." Agricultural Administration and Extension 25 (2): 63-71.

Akoto, O. A. 1987. “Agricultural Development Policy in Ghana." Food Policy 12 (3): 243-254.

Alam, M., and M. Khan. 2008. "Manufacturing of Agricultural Machinery in Bangladesh: Opportunities and Constraints." In Proceedings of the Regional Workshop on Farm Mechanization for Small Holder Agriculture in SAARC Countries. Bhopal, India: South Asian Association for Regional Cooperation.

Amanor, K. S. 2011. "From Farmer Participation to Pro-Poor Seed Markets: The Political Economy of Commercial Cereal Seed Networks in Ghana." IDS Bulletin 42 (4): 48-58.

Aryeetey, E., and W. Baah-Boateng. 2007. Growth, Investment and Employment in Ghana. Working Paper 80. Geneva: Policy Integration Department, International Labor Office.

Benin, S. 2013. Impact of Ghana's Agricultural Mechanization Services Center Program. IFPRI Discussion Paper 01330. Washington, DC: International Food Policy Research Institute.

Benin, S., M. Johnson, K. Jimah, J. Taabazuing, A. Tenga, E. Abokyi, G. Nasser, G. Ahorbo, and V. Owuusu. 2012. "Evaluation of Four Special Initiatives of the Ministry of Food and Agriculture." Draft Report. Washington, DC: International Food Policy Research Institute.

Biggs, S., and S. Justice. 2015. Rural and Agricultural Mechanization: A History of the Spread of Small Engines in Selected Asian Countries. IFPRI Discussion Paper 01443.

Binswanger, H. P. 2017. “Agricultural Mechanization in Sub-Saharan Africa: A Review.” Draft Paper for Accelerating African Poverty Reduction. Mimeo.

Binswanger, H. P., and G. Donovan. 1987. Agricultural Mechanization: Issues and Options. Washington, DC: World Bank.

Binswanger, H. P., and V. W. Ruttan. 1978. Induced Innovations. Baltimore and London: Johns Hopkins University Press.

CEPS. 2012. Ghana Import Data. Accra, Ghana: Customs, Excise and Preventive Services. 
Chapoto, A., N. Houssou, A. Mabiso, and F. Cossar. 2014. Medium and Large-Scale Farmers and Agricultural Mechanization in Ghana: Survey Results. Accra, Ghana: Ghana Strategy Support Program of the International Food Policy Research Institute and Savanna Agricultural Research Institute.

Cossar, F. 2015. Are Boserupian Explanations of Mechanization Use Adequate to Explain the Local Concentration of Agricultural Mechanization in Ghana? Washington, DC: International Food Policy Research Institute.

Diao, X., F. Cossar, N. Houssou, and S. Kolavalli. 2014. "Mechanization in Ghana: Emerging Demand and the Search for Alternative Supply Models." Food Policy 48: 168-181.

Girdner, J., V. Olorunsola, M. Froning, and E. Hansen. 1980. “Ghana’s Agricultural Food Policy: Operation Feed Yourself." Food Policy 5(1): 14-25.

GSS. 2014. Ghana Living Standards Survey Data (Rounds 2-6). Ghana Statistical Service, Accra, Ghana.

_. 2016. 2015 Labor Force Survey Report. Accra, Ghana: Ghana Statistical Service.

Hayami, Y., and V. Ruttan. 1970. "Factor Prices and Technical Change in Agricultural

Development: The United States and Japan.” Journal of Political Economy 78(5): 1115-1141.

— 1985. Agricultural Development: An International Perspective. Baltimore: Johns Hopkins University Press.

Houssou, N., C. Asante-Addo, X. Diao, and S. Kolavalli. 2015. Big Tractors but Small Farms: Tractor Hiring Services as a Farmer-Owner's Response to an Under-Developed Agricultural Machinery Market. Ghana Strategy Support Program Working Paper 39. Washington, DC: International Food Policy Research Institute.

Houssou, N., X. Diao, F. Cossar, S. Kolavalli, K. Jimah, and P. Aboagye. 2013a. “Agricultural Mechanization in Ghana: Is Specialization in Agricultural Mechanization a Viable Business Model?" American Journal of Agricultural Economics 95 (5): 1237-1244.

Houssou, N., X. Diao, and S. Kolavalli. 2014a. Economics of Tractor Ownership under Rainfed Agriculture with Applications in Ghana. IFPRI Discussion Paper 01387. Washington, DC: International Food Policy Research Institute.

-2014b. Can the Private Sector Lead Agricultural Mechanization in Ghana? Ghana Strategy Support Program Policy Note 4. Washington, DC: International Food Policy Research Institute.

Houssou, N., S. Kolavalli, E. Bobobee, and V. Owusu. 2013b. Animal Traction in Ghana. Ghana Strategy Support Program Working Paper 34. Washington, DC: International Food Policy Research Institute. 
Jayne, T. S., J. Chamberlin, L. Traub, N. Sitko, M. Muyanga, F. Yeboah, W. Anseeuw, A. Chapoto, A. Wineman, C. Nkonde, and R. Kachule. 2016. “Africa’s Changing Farm Size Distribution Patterns: The Rise of Medium-Scale Farms." Agricultural Economics 47 (S1): 197-214.

Kienzle, J., J. E. Ashburner, and B. G. Sims. 2013. Mechanization for Rural Development: A Review of Patterns Progress from around the World. Rome: Food and Agriculture Organization of the United Nations.

Nin-Pratt, A., and L. McBride. 2014. "Agricultural Intensification in Ghana: Evaluating the Optimist's Case for a Green Revolution.” Food Policy 48: 153-167.

Okolie, A. C. 2003. "Development Hegemony and the Development Crisis in Africa: The Importance of Indigenous Knowledges and Practices in the Making of Food Policy." The Journal of African American History 88 (4): 429-448.

Oluka, S. 2000. "Costs of Tractor Ownership under Different Management Systems in Nigeria." Nigerian Journal of Technology 19: 15-28.

Pingali, P., Y. Bigot, and H. Binswanger. 1987. Agricultural Mechanization and the Evolution of Farming Systems in Sub-Saharan Africa. Baltimore: Johns Hopkins University Press.

Ruthenburg, H. 1980. Farming Systems in the Tropics. Oxford, UK: Oxford University Press.

Seager, P., and R. Fieldson. 1984. Public Tractor Hire and Equipment Hire Schemes in Developing Countries (with Special Emphasis on Africa). Research Unit Report No. ARU 30. Washington, DC: Agriculture and Rural Development Department, World Bank.

Stryker, J. D., E. Dumeau, J. Wohl, P. Haymond, A. Cook, and K. Coon. 1990. Trade, Exchange Rate, and Agricultural Pricing Policies in Ghana. Washington, DC: World Bank.

Takeshima, H., H. Edeh, A. Lawal, and M. Isiaka. 2015. Characteristics of Private-Sector Tractor Service Provisions: Insights from Nigeria. Developing Economies 53 (3): 188-217.

Takeshima, H., K. Jimah, S. Kolavalli, X. Diao, and R. L. Funk. 2013. Dynamics of Transformation: Insights from an Exploratory Review of Rice Farming in the Kpong Irrigation Project. IFPRI Discussion Paper 01272. Washington, DC: International Food Policy Research Institute.

USAID/ACDI-VOCA. 2013. ADVANCE Tractor Census of Northern Ghana.

World Bank. 2014. Agribusiness Indicators: Synthesis Report. Agriculture Global Practice Discussion Paper 01. Washington, DC: World Bank Group.

Yang, J., Z. Huang, X. Zhang, and T. Reardon. 2013. “The Rapid Rise of Cross-Regional Agricultural Mechanization Services in China." American Journal of Agricultural Economics 95(5): 1245-1251. 